\title{
Pharmacokinetics and Pharmacodynamics of Pirmenol Enantiomers in Coronary Artery Ligated Dogs
}

\author{
Nancy Janiczek ${ }^{\dagger \ddagger}$, David E. Smith ${ }^{\dagger x}$, Tsun Chang ${ }^{\ddagger}$, Anthony Ventura ${ }^{\S}$, and Thomas E. Mertz $\$$ \\ Received August 29, 1996, from the ${ }^{\dagger}$ College of Pharmacy and Upjohn Center for Clinical Pharmacology, 4302A Upjohn Center, \\ 1310 E. Catherine Street, The University of Michigan, Ann Arbor, MI 48109-0504, and the ¥Department of Pharmacokinetics and Drug \\ Metabolism and \$Department of Pharmacology, Parke-Davis Pharmaceutical Research, Division of Warner-Lambert Company, \\ Ann Arbor, MI 48105. Accepted for publication December 19, $1996^{\otimes}$.
}

\begin{abstract}
The pharmacokinetics and pharmacodynamics of pirmenol enantiomers were investigated in coronary artery ligated mongrel dogs. Reduction in frequency of premature ventricular complexes (PVCs) was determined following intravenous administration of $5-\mathrm{mg} / \mathrm{kg}$ doses of racemic pirmenol $(n=5),(+)$-pirmenol $(n=4)$, and $(-)$-pirmenol $(n=$ 4), each given as a 5-min infusion. Electrocardiographic signals and blood samples were obtained serially over a 4-h period. Pirmenol enantiomer concentrations in plasma were determined by a stereospecific assay. Following the racemate dose, (-)-pirmenol had $47 \%$ lower clearance and $33 \%$ lower steady-state distribution volume than (+)pirmenol. These differences could be mostly explained by stereoselective plasma protein binding, reflected in a $58 \%$ higher unbound fraction for (+)-pirmenol compared with (-)-pirmenol following racemate administration. Unbound pirmenol distribution volumes were nearly identical for both enantiomers, and unbound clearance was only $16 \%$ lower for (-)-pirmenol than (+)-pirmenol following administration of the racemate. Similar trends were observed for pirmenol enantiomers administered individually. Both pirmenol enantiomers were equally effective in arrhythmia suppression. The antiarrhythmic response of coronary artery ligated dogs to pirmenol was described by a sigmoid $E_{\max }$ model, and no statistically significant differences were observed in the pharmacodynamic parameters [i.e., $\mathrm{EC}_{50}$ (plasma concentration at $50 \%$ of maximum drug effect), $S$ (constant that reflects the sigmoidal shape of the effect-concentration curve), and $\mathrm{EC}_{90}$ (plasma concentration at $90 \%$ of maximum drug effect)] for (+)-pirmenol, (-)-pirmenol, or pirmenol racemate.
\end{abstract}

\section{Introduction}

Stereoisomerism is an important consideration in drug development because the enantiomers of an optically active compound may differ in their interaction with other chiral molecules. Many biological molecules are chiral in nature, so the potential exists for sel ective interactions between these molecules and opposing enantiomers of chiral drugs. Enantiomers of a drug may show substantial differences in their pharmacological activity, and when this occurs, enantiomer differences in pharmacokinetics can become important determinants of drug response.

Pirmenol is a chiral compound, and the racemic mixture is being investigated as an antiarrhythmic agent. Pirmenol is considered as a Class I antiarrhythmic because its primary effect is blocking sodium channels in the cardiac cell membrane. Many other drugs in the same class are chiral, including disopyramide, cibenzoline, tocainide, mexiletine, flecainide, encainide, and propafenone, and are administered as racemic mixtures.

Pirmenol racemate was shown to be effective in suppression of premature ventricular contractions (PVCs) following coronary artery ligation in dogs. ${ }^{1-3}$ However, antiarrhythmic

\footnotetext{
${ }^{\otimes}$ Abstract published in Advance ACS Abstracts, February 1, 1997.
}

effects may not be produced equally by both enantiomers. In dog models of ventricular arrhythmia, enantiomers of tocainide, $^{4} \mathrm{flecainide}^{5}$ propranolol, 6 and sotal ol 7 showed equival ent antiarrhythmic effects, but mexiletine demonstrated a stereoselective difference where $\mathrm{R}-(-)$-mexiletine was more potent in prevention of ventricular tachycardia than S-(+)mexiletine in dogs. ${ }^{8}$ Furthermore, both disopyramide and propranolol showed stereoselective pharmacokinetic properties. ${ }^{9-13}$ Clearance of S-(+)-disopyramide in dogs was nearly $50 \%$ higher than that of R-(-)-disopyramide, with no enantiomer difference in distribution volume. ${ }^{9,14}$ Cook et al. ${ }^{10}$ also observed stereoselective clearance of disopyramide in dogs, demonstrating a $40 \%$ higher renal clearance and greater firstpass metabolism for $\mathrm{S}-(+)$-disopyramide, with $\mathrm{N}$-dealkylation being a stereoselective metabolic pathway. In addition, several investigators have reported stereoselective hepatic metabolism of S-(-)-propranolol in dogs. ${ }^{11-13,15}$

In this study, possible differences in pharmacokinetics and pharmacodynamics of pirmenol enantiomers were investigated to provide information regarding any potential benefit in the use of either pirmenol enantiomer rather than the racemate. To determine the relative contribution of pirmenol enantiomers to the overall antiarrhythmic effect, (+)-pirmenol, (-)pirmenol, and pirmenol racemate were each tested in the model of induced ventricular arrhythmia in dogs, which was initially used in the study of pirmenol racemate. Pharmacokinetics of pirmenol enantiomers were also studied in these animals.

\section{Experimental Section}

Study Design-Reduction in frequency of PVCs following intravenous (iv) administration of 5-mg/kg doses of pirmenol racemate ( $\mathrm{n}$ $=5),(+)$-pirmenol $(n=4)$, and $(-)$-pirmenol $(n=4)$ was determined in coronary artery ligated mongrel dogs of either gender weighing 8.1 to $13.0 \mathrm{~kg}$ (mean $10.4 \mathrm{~kg}$ ). Dogs were anesthetized with pentobarbital sodium (35 mg/kg, iv), and the left anterior descending coronary artery was ligated by a two-stage procedure as described by Harris. ${ }^{16}$ A lead II electrocardiogram (ECG) was monitored on the first day after surgery with a Gould 220 polygraph. Analysis of the ECG record was performed by the method of Moran et al. ${ }^{17}$ in which ventricular beats of apparent sinus origin were considered normal and all other ventricular beats were classified as ectopic. Dogs were excluded from testing if $>50 \%$ normal sinus beats were observed or if total ventricular rate exceeded 200 beats/min. The dogs were studied in the conscious state (1 day post-infarction) while resting comfortably suspended in slings.

Predose baseline arrhythmia was determined as the average number of PVCs/min during the final $20 \mathrm{~min}$ before dosing. The ECG readings ( $20 \mathrm{~s}$ each) were obtained every minute during the infusion and for the first $5 \mathrm{~min}$ after the infusion, every $5 \mathrm{~min}$ for the first hour post-infusion, and every $15 \mathrm{~min}$ from 1 to $4 \mathrm{~h}$ following the end of the infusion. Additional ECG readings were obtained 1 min before and 1 min after each blood sampling time, and the three ECG values (PVCs/min) were averaged. Pirmenol doses were dissolved in $10 \mathrm{~mL}$ of $0.9 \%$ saline and administered as a 5 -min infusion via the femoral artery. Blood samples ( $1.5 \mathrm{~mL}$ ) were obtained before dosing (blank), at the end of the 5-min infusion, and at 5, 10, 20, 30, 45, 60, 90, 120, 
180, and 240 min post-infusion. Plasma was separated and assayed the same day or stored frozen at $-20^{\circ} \mathrm{C}$ until analysis.

Quantitation of Pirmenol Enantiomers-Plasma pirmeno enantiomer concentrations were determined by a stereospecific liquid chromatographic assay, ${ }^{18}$ except that a $0.25-\mathrm{mL}$ sample (diluted with $0.25 \mathrm{~mL}$ of blank dog plasma) was used. Briefly, racemic pirmenol and internal standard [(+)-propranolol ] were isolated from dog plasma by a three-step extraction procedure using toluene, $0.1 \mathrm{~N} \mathrm{HCl}$, and hexane, respectively. A cellulose-bonded chiral analytical column (Chiralcel OJ ) was used, with a mobile phase consisting of hexane: isopropanol:diethylamine (98.9:1.0:0.1) and with detection by ultraviolet (UV) absorbance at $262 \mathrm{~nm}$. Linear calibration curves were obtained in the concentration range of 0.0200 to $5.00 \mu \mathrm{g} / \mathrm{mL}$ for each enantiomer. The precision of the method was $\leq 7.1 \%$ for both enantiomers, and bias was $\pm 2.2 \%$ for (+)-pirmenol and $\pm 1.5 \%$ for (-)pirmenol. Neither enantiomer was observed in chromatograms following administration of the opposite enantiomer to coronary artery ligated dogs. Therefore, pirmenol enantiomer conversion did not occur in vivo nor did it occur during sample analysis.

Unbound concentrations were determined in each study sample by equilibrium dialysis. Plasma containing pirmenol $(0.75 \mathrm{~mL})$ was dialyzed against an equal volume of isotonic $\mathrm{pH} 7.4$ phosphate buffer in a $37^{\circ} \mathrm{C}$ shaking water bath for $4 \mathrm{~h}$ (equilibrium was reached, as indicated by preliminary experiments). Plasma and buffer samples were assayed for pirmenol enantiomer concentrations by a liquid chromatographic method. 18

Pharmacokinetic Data Analysis-Postinfusion plasma pirmenol concentration $\left(C_{p}\right)$-time (t) data were fitted to the following polyexponential equation:

$$
C_{p}=\sum_{i=1}^{n} Y_{i} e^{-\lambda_{i} t}
$$

in which parameter estimates $\left(Y_{i}, \lambda_{i}\right)$ were obtained by nonlinear leastsquares regression (RSTRIP, Version 4, MicroMath Scientific Software, Salt Lake City, UT). The number of exponents used in the equation and weighting factor (1, 1/concentration, or $1 /$ concentration $^{2}$ ) were selected based on coefficient of determination $\left(r^{2}\right)$, standard deviation of the parameter estimates, and visual inspection of the residuals. Coefficients were corrected for infusion time (T) with the following equation:

$$
C_{i}=\frac{Y_{i} \lambda_{i} T}{e^{\lambda_{i} T}-1}
$$

Pharmacokinetic parameters were then calculated with standard equations. ${ }^{19,20}$ The pharmacokinetics of unbound pirmenol were determined by the same methods.

Linear or nonlinear binding was assessed from a plot of $\mathrm{Cb}^{\prime \prime}$ as a function of $C f^{\prime}$. For linear binding, fraction unbound in plasma $\left(f_{u}\right)$ was calculated with eq $3^{21}$ :

$$
f_{u}=\frac{C f^{\prime}}{C f^{\prime}+C b^{\prime \prime}}
$$

in which $\mathrm{Cf}^{\prime}$ is the unbound concentration of pirmenol in buffer after dialysis, and $\mathrm{Cb}^{\prime \prime}$ is the volume-corrected bound concentration of pirmenol in plasma after dialysis.

For nonlinear binding, $\mathrm{Cb}^{\prime \prime}$ versus $\mathrm{Cf}^{\prime}$ data were best fit to a single Langmuir equation:

$$
C b^{\prime \prime}=\frac{P(1) \cdot C f^{\prime}}{P(2)+C f^{\prime}}
$$

where $P(1)$ and $P(2)$ are capacity and dissociation constants, respectively. Nonlinear regression was performed with the program MINSQ II (Version 1.02, MicroMath Scientific Software, Salt Lake City, UT), with a weighting factor of unity. Goodness of fit criteria included coefficient of determination $\left(r^{2}\right)$, standard deviation of parameter estimates, and visual inspection of residuals. Since total concentration (Cp) is the sum of bound (Cb) and unbound (Cf) concentrations in plasma, total concentration can be expressed as follows:

$$
C p=\frac{P(1) \cdot C f}{P(2)+C f}+C f
$$

Equation 5 can be rearranged to a quadratic equation (eq 6) that was solved for unbound concentration (Cf) using the total concentration in the original plasma sample (Cp) and estimates of $\mathrm{P}(1)$ and $\mathrm{P}(2)$ :

$$
C f^{2}+(P(1)+P(2)-C p) \cdot C f-C p \cdot P(2)=0
$$

The time-averaged fraction unbound in plasma $\left(\mathrm{f}_{\mathrm{u}}\right)$ was then estimated as follows:

$$
\mathrm{f}_{\mathrm{u}}=\frac{\operatorname{A\cup C}(0-\infty)_{\text {unbound }}}{\operatorname{AUC}\left(0_{-\infty}\right)_{\text {total }}}
$$

Pharmacodynamic Data Analysis-The pharmacol ogic effect of pirmenol was measured as the percent reduction in PVCs/min from the pre-study baseline value. At each blood sampling time, PVCs were averaged for ECG readings obtained 1 min before, during, and 1 min after the sampling time. Effect measurements obtained postinfusion without simultaneous blood sample collection were paired with plasma drug concentrations that were calculated with parameter estimates obtained from pharmacokinetic data analysis. Effectconcentration profiles were fitted to a sigmoid $\mathrm{E}_{\max }$ equation, as shown in eq 8:

$$
E=\frac{E_{\max } \cdot C^{S}}{E C_{50}{ }^{S}+C^{S}}
$$

where $\mathrm{E}$ is the percent reduction in PVCs from baseline; $\mathrm{E}_{\max }$ is the maximum drug effect; $C$ is the plasma pirmenol concentration $(\mu \mathrm{g} /$ $\mathrm{mL}) ; \mathrm{EC}_{50}$ is the plasma concentration at $50 \%$ of $\mathrm{E}_{\max }(\mu \mathrm{g} / \mathrm{mL})$; and $\mathrm{S}$ is a constant that reflects the sigmoid shape of the effect-concentration curve. The $E_{\max }$ value was held constant at $100 \%$ because complete abolition of PVCs was evident with pirmenol. The $\mathrm{EC}_{50}$ and $S$ values were estimated by nonlinear least squares regression with the program MINSQ II and a weighting factor of unity. Because effect is defined as percent reduction in PVCs, the maximum possible effect that can be achieved is $100 \%$. The effective therapeutic concentration was determined as the plasma drug concentration at $90 \%$ PVC reduction $\left(\mathrm{EC}_{90}, \mu \mathrm{g} / \mathrm{mL}\right)$. The $\mathrm{EC}_{90}$ values were calculated with the parameter estimates and a rearrangement of eq 8 , such that $E_{90}=$ $\mathrm{EC}_{50} /(0.111)^{1 / 5}$.

Statistical Analysis-Enantiomer differences in mean pharmacokinetic parameters were evaluated by a paired t test following administration of pirmenol racemate and an unpaired t test following administration of the individual enantiomers. Mean pharmacokinetic parameters following the racemate dose were compared with parameters obtained following the enantiomer dose by unpaired t tests. Mean pharmacodynamic parameters were compared by analysis of variance. A $p$ value of $\leq 0.05$ was considered significant in all statistical tests.

\section{Results and Discussion}

Pharmacokinetics of Pirmenol Enantiomers-Pirmenol plasma concentration-time data were fitted to eq 1 with either 1, 2, or 3 exponents. In each case, a weighting factor of $1 /$ concentration ${ }^{2}$ was used. Coefficients of determination ranged from 0.968 to 0.998 for those analyses using total pirmenol, and from 0.893 to 0.999 for those analyses using unbound pirmenol. Pharmacokinetic parameters for total and unbound pirmenol enantiomers following the racemic dose and following individual enantiomer administration are given in Table 1. Plasma total (-)-pirmenol concentrations exceeded total (+)-pirmenol concentrations following administration of the racemate as well as following separate administration of each enantiomer at equal doses (Figure 1 ). The AUC $(0-\infty)$ values were approximately twofold greater for total (-)-pirmenol than for total (+)-pirmenol following pirmenol racemate and this difference was statistically signifi- 
Table 1-Mean ( \pm SD) Pharmacokinetic Parameters of Pirmenol Enantiomers in Coronary Artery Ligated Dogs Following a Single Intravenous Dose of 5 $\mathrm{mg} / \mathrm{kg}$ Given as Pirmenol Racemate $(n=5),(+)$-Pirmenol $(n=4)$, or $(-)$-Pirmenol $(n=4)^{a}$

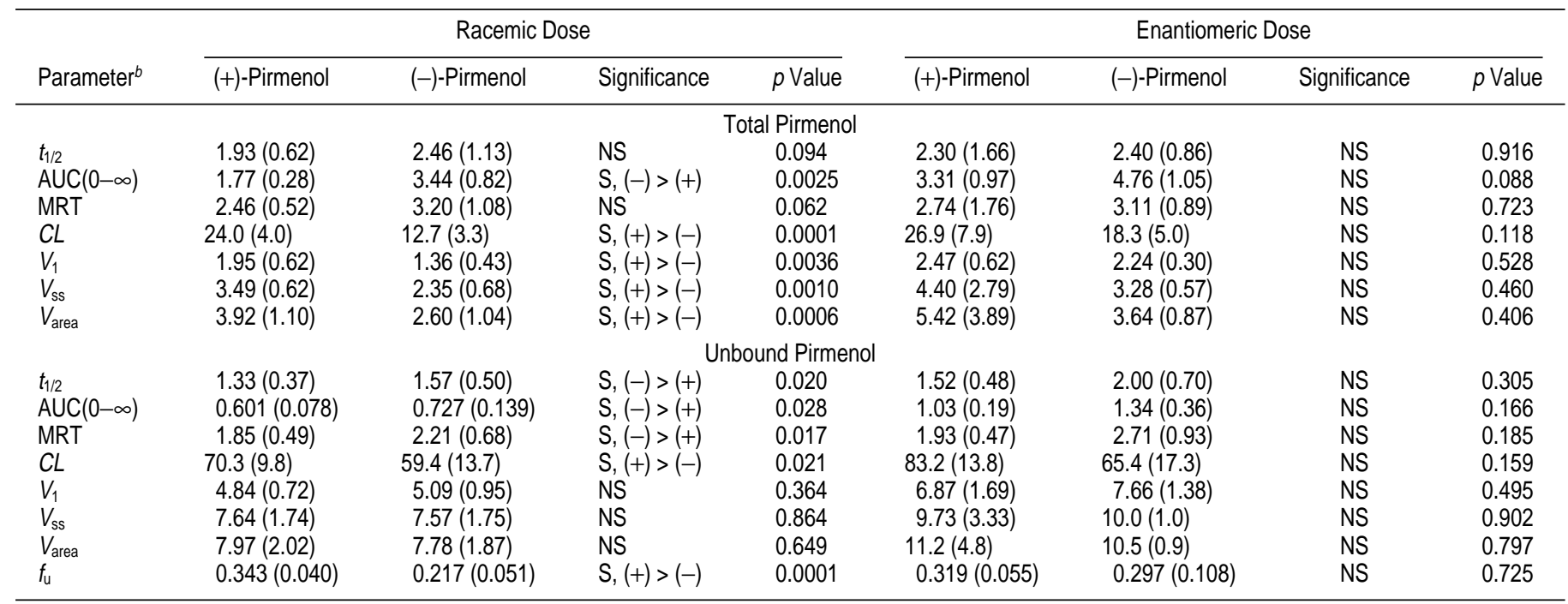

${ }^{a}$ Body weight $=10.0 \pm 1.2 \mathrm{~kg}$ for racemate dose group (mean $\pm \mathrm{SD}$ ); $9.7 \pm 1.5 \mathrm{~kg}$ for (+)-pirmenol dose group (mean $\pm \mathrm{SD}$ ); and $11.6 \pm 1.1 \mathrm{~kg}$ for $(-$ )-pirmenol dose group (mean $\pm \mathrm{SD}$ ). ${ }^{b}$ Parameter definitions: $t_{1 / 2}=$ terminal-phase half-life $(\mathrm{h}) ; \mathrm{AUC}(0-\infty)=$ area under the plasma concentration-time curve extrapolated to infinity $(\mu \mathrm{g} \cdot \mathrm{h} / \mathrm{mL}) ; \mathrm{MRT}=$ mean residence time $(\mathrm{h}) ; C L=$ plasma clearance $(\mathrm{mL} / \mathrm{min} / \mathrm{kg}) ; V_{1}=$ volume of the central compartment $(\mathrm{L} / \mathrm{kg}) ; V_{s s}=$ volume of distribution steady-state $(\mathrm{L} / \mathrm{kg}) ; V_{\text {area }}=$ volume relating plasma drug concentration to amount in the body during the log-linear terminal phase $(\mathrm{L} / \mathrm{kg}) ; f_{u}=$ fraction unbound in plasma.

cant (S). The difference between AU C $\left(0_{-\infty}\right)$ values following individual enantiomer administration was not statistically significant (NS) even though total (-)-pirmenol AUC $(0-\infty)$ was $44 \%$ greater than for total (+)-pirmenol. Clearance of total drug was $47 \%$ lower (S) for (-)-pirmenol than for (+)-pirmenol following the racemate dose and 32\% lower (NS) for (-)pirmenol following individual enantiomer doses. Similar to the significantly higher plasma clearance for (+)-pirmenol than for (-)-pirmenol, stereoselective clearance was also observed for disopyramide and propranolol in dogs, where clearance of S-(+)-disopyramide and S-(-)-propranolol exceeded their R-enantiomers by 40 to $50 \%$ and by two- to threefold, respectively. ${ }^{9-12,14}$ Volume of distribution parameters $\left(\mathrm{V}_{1}, \mathrm{~V}_{\mathrm{ss}}, \mathrm{V}_{\text {area }}\right)$ were $\sim 50 \%$ larger for total (+)-pirmenol than for total (-)-pirmenol (S) following the racemate, and 10-49\% larger for (+)-pirmenol than for (-)-pirmenol (NS) following individual enantiomer administration. There were no significant differences between enantiomers in elimination half-life and mean residence time whether pirmenol was given as the racemate or the individual enantiomers.

Although the trends in pharmacokinetic differences were similar following both individual pirmenol enantiomer and racemate administration, none of these enantiomer differences were statistically significant following individual enantiomer doses. This result was not unexpected because enantiomers could be compared by a paired t test following racemate administration and an unpaired t test was necessary to compare the two separate groups of dogs receiving individual enantiomers. The power of a paired t test for enantiomer comparisons following pirmenol racemate made the detection of statistically significant differences more likely relative to enantiomer comparisons following individual enantiomer doses.

Plasma protein binding was more extensive for (-)-pirmenol than for (+)-pirmenol. Mean fraction unbound was $58 \%$ higher (S) for (+)-pirmenol than for (-)-pirmenol following the racemate dose, and 7\% higher (NS) for (+)-pirmenol following individual enantiomer doses. Plasma protein binding was linear for most dogs, with only three of the 13 dogs tested showing nonlinear protein binding. Of these three dogs, one received pirmenol racemate and the other two received (+)pirmenol alone.

Higher (-)-pirmenol concentrations observed for total pirmenol can, at least in part, be explained by differences in extent of plasma protein binding. Differences in total pirmenol enantiomer concentrations were minimized when unbound concentrations were compared. Clearance of unbound (-)pirmenol was only $16 \%$ lower (S) following administration of the racemate and $21 \%$ lower (NS) following administration of the individual enantiomers, relative to unbound (+)pirmenol. Distribution volume terms for unbound drug were similar for both (+)- and (-)-pirmenol, whether administered as pirmenol racemate or as the individual enantiomers. As a result of lower clearance for unbound (-)-pirmenol with no enantiomer difference in unbound pirmenol distribution volume, half-life was longer for unbound (-)-pirmenol than for unbound (+)-pirmenol.

Possible interaction between enantiomers was assessed by comparing pharmacokinetic parameters for each enantiomer given as the racemate or as the individual enantiomer by an unpaired t test. Several distribution volume terms (i.e., unbound (+)-pirmenol $\mathrm{V}_{1}$, total (-)-pirmenol $\mathrm{V}_{1}$, and unbound (-)-pirmenol $\mathrm{V}_{1}, \mathrm{~V}_{\mathrm{sS}}$, and $\mathrm{V}_{\text {area }}$ ) were $30-60 \%$ greater (S) following individual enantiomer administration compared with racemate. Lower distribution volume following the racemate compared with the individual enantiomers may suggest the possibility of decreased tissue binding when both enantiomers are present compared with when each enantiomer is administered alone. In contrast, there were no significant differences between enantiomer alone and enantiomer in the presence of its optical antipode with respect to clearance, half-life, and plasma protein binding.

Pharmacodynamics of Pirmenol Racemate and E nantiomers-Basel ine arrhythmia ranged from 138 to 172 PVCs/min, 118 to $199 \mathrm{PVCs} / \mathrm{min}$, and 149 to $207 \mathrm{PVCs} / \mathrm{min}$ in dogs receiving (+)-pirmenol, (-)-pirmenol, and pirmenol racemate, respectively. Expressed as percent of total beats, basel ine values ranged from 89-97\% PVCs, 92-100\% PVCs, and $80-100 \%$ PVCs in dogs receiving (+)-pirmenol, (-)pirmenol, and pirmenol racemate, respectively. Therefore, similar degrees of arrhythmia were used for comparison 

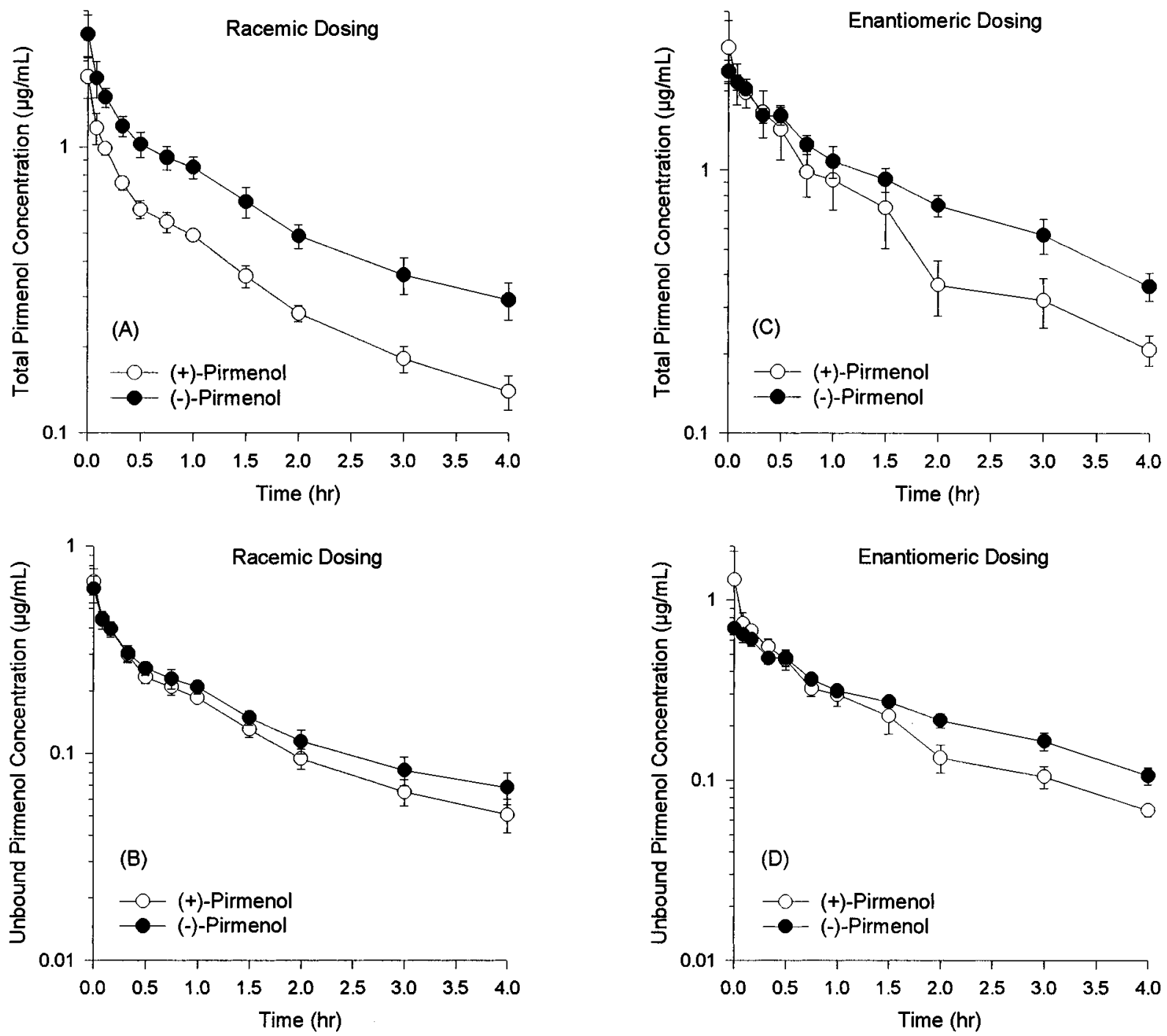

Figure 1-Mean $( \pm S E)$ plasma concentrations of total $(A)$ and unbound $(B)$ pirmenol enantiomers following a single iv 5 -mg/kg racemic pirmenol dose to coronary artery ligated dogs $(n=5)$; mean $( \pm S E)$ plasma concentrations of total $(C)$ and unbound $(D)$ pirmenol enantiomers following a single iv 5 -mg/kg $(+)$-pirmenol dose $(n$ $=4)$ and $(-)$-pirmenol dose $(n=4)$ to coronary artery ligated dogs.

Table 2-Statistical Comparison of Mean ( \pm SD) Pharmacodynamic Parameters of Pirmenol Enantiomers and Pirmenol Racemate in Coronary Artery Ligated Dogs Following a Single Intravenous Dose of $5 \mathrm{mg} / \mathrm{kg}$ Given As Pirmenol Racemate $(n=5),(+)$-Pirmenol $(n=4)$, or $(-)$-Pirmenol $(n=4)$

\begin{tabular}{|c|c|c|c|c|c|}
\hline \multirow[b]{2}{*}{ Parameter $^{a}$} & \multicolumn{3}{|c|}{ Dose } & \multirow[b]{2}{*}{ Significance } & \multirow[b]{2}{*}{$p$ Value } \\
\hline & Racemate & (+)-Pirmenol & (-)-Pirmenol & & \\
\hline $\begin{array}{l}\% \text { of Total Beats } \\
\text { PVCs } / \text { min }\end{array}$ & $\begin{array}{c}94(8) \\
172(24)\end{array}$ & $\begin{array}{l}\text { Baseline } \\
94(3) \\
149(15)\end{array}$ & $\begin{array}{c}96(4) \\
158(45)\end{array}$ & $\begin{array}{l}\text { NS } \\
\text { NS }\end{array}$ & $\begin{array}{l}0.804 \\
0.550\end{array}$ \\
\hline $\begin{array}{l}\mathrm{EC}_{50} \\
S \\
\mathrm{EC}_{90} \\
r^{2}\end{array}$ & $\begin{array}{l}1.43(0.65) \\
2.77(2.75) \\
5.72(3.75) \\
0.566(0.148)\end{array}$ & $\begin{array}{l}\quad \text { Total P } \\
1.20(0.28) \\
2.27(0.74) \\
3.51(0.82) \\
0.745(0.108)\end{array}$ & $\begin{array}{l}1.08(0.33) \\
4.76(2.82) \\
1.96(0.77) \\
0.769(0.181)\end{array}$ & $\begin{array}{l}\text { NS } \\
\text { NS } \\
\text { NS }\end{array}$ & $\begin{array}{l}0.532 \\
0.325 \\
0.116\end{array}$ \\
\hline $\begin{array}{l}\mathrm{EC}_{50} \\
S \\
\mathrm{EC}_{90} \\
r^{2}\end{array}$ & $\begin{array}{l}0.41(0.16) \\
2.17(1.78) \\
1.82(1.20) \\
0.550(0.152)\end{array}$ & $\begin{array}{l}\quad \text { Unbound } \\
0.43(0.10) \\
2.18(0.67) \\
1.33(0.47) \\
0.748(0.107)\end{array}$ & $\begin{array}{l}0.35(0.18) \\
4.70(2.59) \\
0.62(0.34) \\
0.767(0.180)\end{array}$ & $\begin{array}{l}\text { NS } \\
\text { NS } \\
\text { NS }\end{array}$ & $\begin{array}{l}0.743 \\
0.124 \\
0.145\end{array}$ \\
\hline
\end{tabular}

${ }^{a} \mathrm{EC}_{50}=$ plasma drug concentration at $50 \%$ of $E_{\max }(\mu \mathrm{g} / \mathrm{mL}) ; \mathrm{EC}_{90}=$ plasma drug concentration at $90 \%$ of $E_{\max }(\mu \mathrm{g} / \mathrm{mL})$.

between treatment groups (Table 2). In previous studies of pirmenol racemate, Mertz and co-workers ${ }^{1,2}$ showed that the arrhythmia produced with the Harris dog model was stable for a treatment period of at least $6 \mathrm{~h}$ on the day after surgery. Arrhythmia was monitored for $4 \mathrm{~h}$ post-dose in this study, so the observed reduction in PVCs can be attributed to a drug 

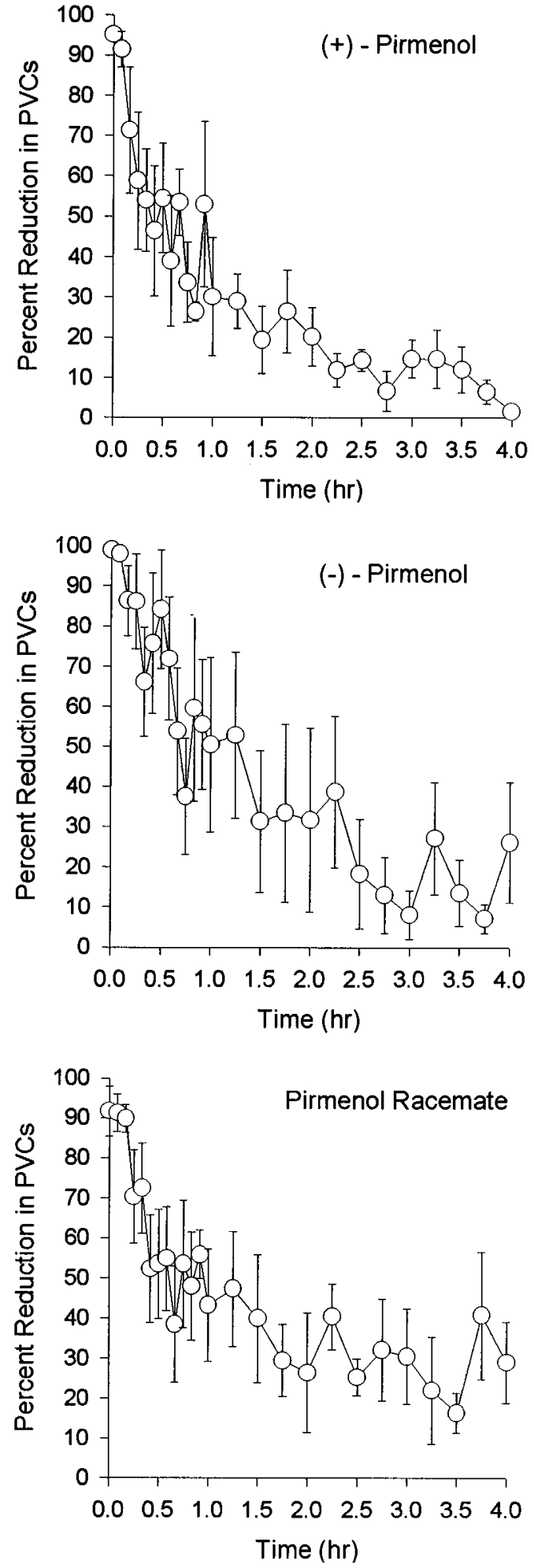

Figure 2-Mean $( \pm S E)$ effect versus time profiles in coronary artery ligated dogs following a single iv dose of $5 \mathrm{mg} / \mathrm{kg}$ of (+)-pirmenol, (-)-pirmenol, or pirmenol racemate.

effect without significant contribution from a natural return of sinus rhythm with time following surgery.

Both pirmenol enantiomers were equally effective in arrhythmia suppression. Pirmenol racemate also showed PVC reduction similar to that of the individual enantiomers at equivalent doses. For all threetreatments, suppression of the arrhythmia was complete or nearly complete by the end of the 5-min infusion. Following the infusion, PVCs returned
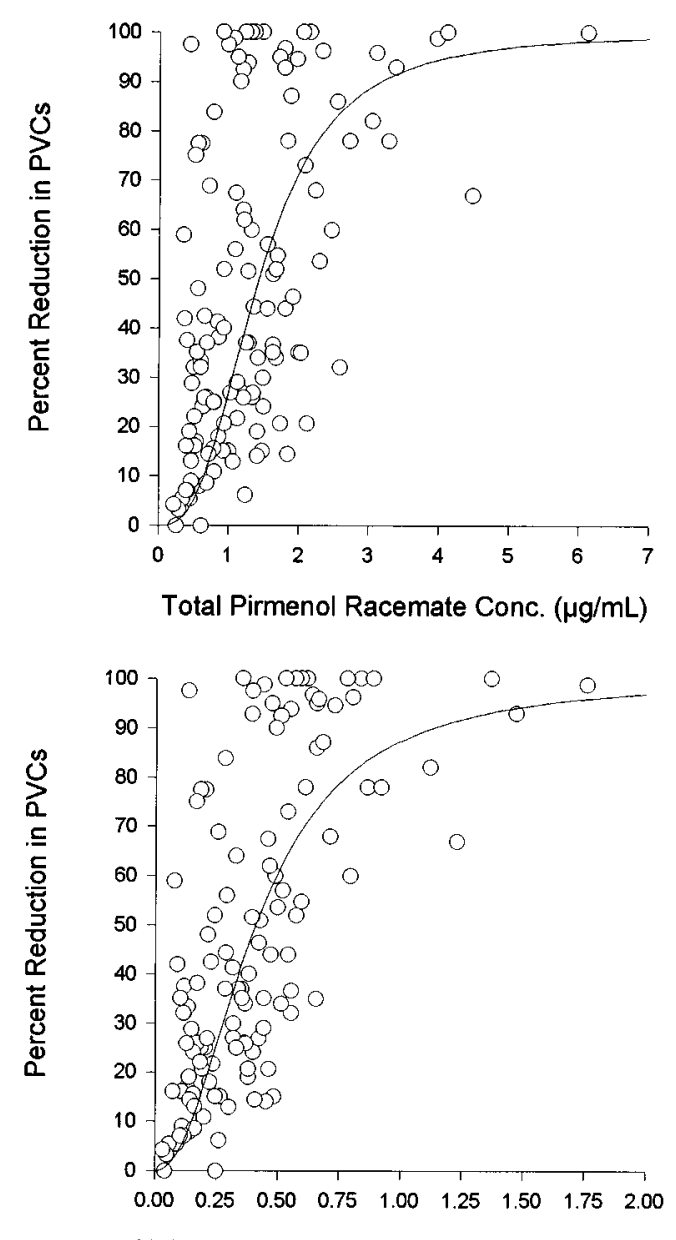

Unbound Pirmenol Racemate Conc. $(\mu \mathrm{g} / \mathrm{mL})$

Figure 3-Effect-concentration profiles of total and unbound pirmenol racemate in coronary artery ligated dogs following a single iv dose of $5 \mathrm{mg} / \mathrm{kg}$ of pirmenol racemate. The solid line represents the hypothetical effect-concentration curve based on mean $\mathrm{EC}_{50}$ and $S$ values as displayed in Table 2. Individual data are superimposed on this curve.

with time as drug was being cleared from the systemic circulation (Figure 2).

Pharmacodynamic parameters are listed in Table 2 for total and unbound pirmenol enantiomers and racemate. Percent reduction in PVCs was correlated with drug concentration with a sigmoid $\mathrm{E}_{\max }$ model (eq 8). Coefficient of determination $\left(r^{2}\right)$ values ranged from 0.405 to 0.901 , and were similar for all drug species. Low $r^{2}$ values were probably a result of spontaneous variability in the effect parameter (PVCs/min), which has been described by Harris. ${ }^{16}$ Mean $\mathrm{EC}_{50}$ values were similar for (+)-pirmenol, (-)-pirmenol, and pirmenol racemate, ranging from 1.08 to $1.43 \mu \mathrm{g} / \mathrm{mL}$ for total drug (NS) and from 0.35 to $0.43 \mu \mathrm{g} / \mathrm{mL}$ for unbound drug (NS). Values for the slope factor were approximately twofold greater (NS) for (-)pirmenol than for (+)-pirmenol or pirmenol racemate. Similarly, therapeutic plasma concentrations reflected by the E $\mathrm{C}_{90}$ values were nearly two- to threefold lower (NS) for (-)pirmenol as compared with (+)-pirmenol and pirmenol racemate; however, these differences were not statistically significant (Table 2). Effect-concentration curves simulated with mean $\mathrm{EC}_{50}$ and $\mathrm{S}$ values reflect the totality of individual data reasonably well for both total and unbound pirmenol racemate (Figure 3). Similar effect-concentration curves were also observed following (+)-pirmenol and (-)-pirmenol. To better highlight these treatment comparisons, the general profiles of effect-concentration curves based on mean param- 

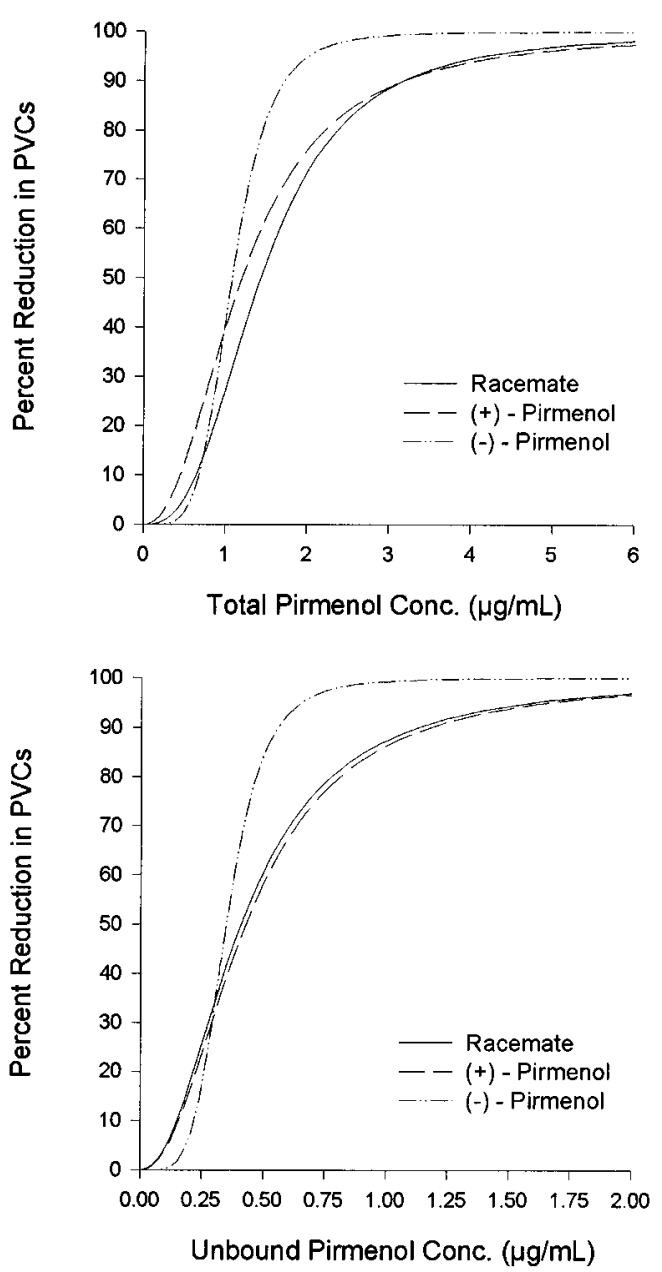

Figure 4-Comparison of fitted effect-concentration curves using mean $\mathrm{EC}_{50}$ and $S$ estimates from Table 2 for total and unbound drug following a single iv dose of $5 \mathrm{mg} / \mathrm{kg}$ of (+)-pirmenol, (-)-pirmenol, or pirmenol racemate to coronary artery ligated dogs.

eter estimates for (+)-pirmenol, (-)-pirmenol, and pirmenol racemate are displayed in Figure 4.

Although the mean $\mathrm{EC}_{90}$ appeared to be lower for (-)pirmenol (NS), greater sensitivity of sodium channels to (-)pirmenol is not likely because Nakaya et al. ${ }^{22}$ showed no stereoselective interaction of pirmenol enantiomers with the sodium channel in guinea pig papillary muscle. Similarity of the phenyl and pyridine rings at the chiral center of the chemical structure of pirmenol was suggested by Nakaya et al. ${ }^{22}$ to be responsible for the lack of stereoselectivity in sodium channel blocking activity. Parameter differences between pirmenol enantiomers may have resulted from different dogs being used in each treatment group and the relatively small number of animals studied. A larger sample size may be necessary to determine if either pirmenol enantiomer was actually more potent. However, it is unlikely that the data for (+)-pirmenol and (-)-pirmenol reflect an actual difference in $\mathrm{EC}_{90}$ between enantiomers. If this were true, then one would predict the $\mathrm{EC}_{90}$ of racemate to be intermediate between the (+)-pirmenol and (-)-pirmenol values. In fact, $\mathrm{EC}_{90}$ values for racemate were apparently larger (NS) than for individual enantiomers, which probably reflects the different animals studied. In addition, individual effect-concentration data for the (+)-pirmenol and (-)-pirmenol doses show a large degree of overlap, with each enantiomer dose extending over a wide range of effect and concentration values (Figure 5).

The severity of arrhythmia may also be a factor in determining the therapeutic concentration required for PVC sup-
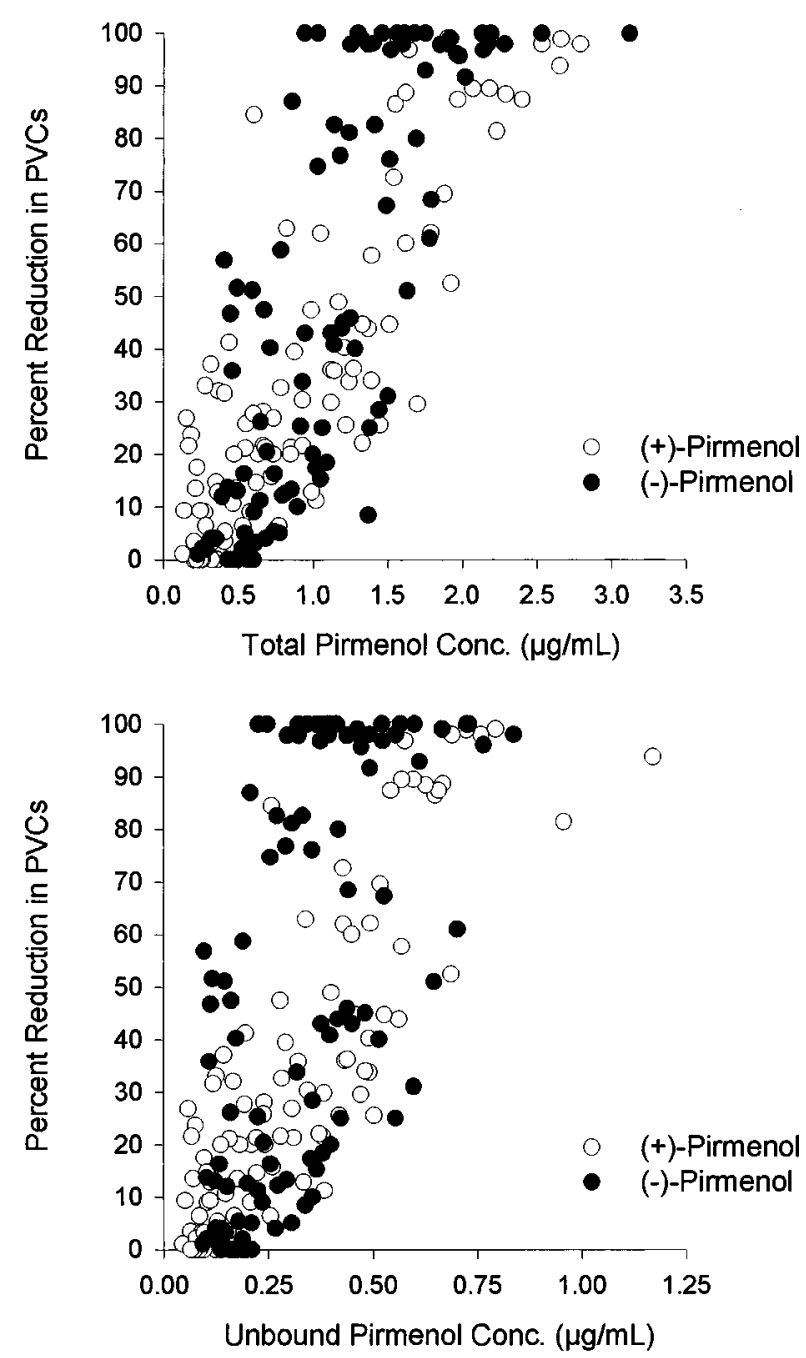

Figure 5-Comparison of pooled effect-concentration data for total and unbound drug following a single iv dose of $5 \mathrm{mg} / \mathrm{kg}$ of $(+)$-pirmenol or $(-)$-pirmenol to coronary artery ligated dogs.

pression because Steffe et al. ${ }^{2}$ showed that higher doses were required for treatment of more severe arrhythmia occurring on the first day as compared with the second day after coronary artery ligation. In another study, minimum effective therapeutic concentration for $100 \%$ PVC suppression by total pirmenol racemate was estimated as $1.0 \mu \mathrm{g} / \mathrm{mL}$ for low-rate arrhythmias (average baseline, 53\% PVCs) and $2.3 \mu \mathrm{g} / \mathrm{mL}$ for high-rate arrhythmias (average baseline, 96\% PVCs) during continuous iv infusion in coronary artery ligated dogs. ${ }^{1}$ In this context, high $\mathrm{EC}_{90}$ values were generally associated with the most severe arrhythmias, and the highest mean baseline PVC rate (PVCs/min) was in the group receiving pirmenol racemate (NS). Although not statistically different, mean $\mathrm{EC}_{90}$ values for the racemate were higher than for the $(+)-$ pirmenol and (-)-pirmenol groups with lower mean baseline PVC rates (Table 2 ).

Mean $( \pm S D)$ minimum effective plasma concentration, defined as the concentration at the last minute of statistically significant decrease in \%PVCs from the predose value, was reported as $1.1 \pm 0.3 \mu \mathrm{g} / \mathrm{mL}$ (corresponding to $65 \%$ reduction in PVCs) in coronary artery ligated dogs; compl ete arrhythmia suppression was observed at concentrations ranging from 0.7 to $4 \mu \mathrm{g} / \mathrm{mL} .{ }^{3}$ These literature values, as well as those reported by Mertz and Steffe, ${ }^{1}$ correspond favorably with the mean effective therapeutic concentration $\left(\mathrm{EC}_{90}\right.$ ) of $5.72 \mu \mathrm{g} / \mathrm{mL}$ (range 
1.19 to $8.83 \mu \mathrm{g} / \mathrm{mL}$ ) for total racemic pirmenol obtained from fitting effect-concentration data to a sigmoid $E_{\max }$ model in this study.

Conclusions-Plasma total (-)-pirmenol concentrations exceeded those of $(+)$-pirmenol, with statistically different values for AUC $(0-\infty)$ [94\% higher for (-)-pirmenol ], CL [47\% lower for (-)-pirmenol], and $\mathrm{V}_{\mathrm{ss}}$ [33\% lower for (-)-pirmenol] following the pirmenol racemate dose. Similar trends were observed for pirmenol enantiomers administered individually; however, the differences did not achieve statistical significance. (+)-Pirmenol showed a 58\% higher unbound fraction in plasma than (-)-pirmenol following racemate administration, so differences between pirmenol enantiomer pharmacokinetic parameters based on unbound plasma drug concentrations were dramatically reduced. Unbound pirmenol distribution volumes were nearly identical for both enantiomers, and small statistical differences were observed for unbound $\mathrm{AUC}(0-\infty)$ [17\% higher for (-)-pirmenol] and unbound dearance [ $16 \%$ lower for (-)-pirmenol] following the racemate. Therefore, differences between total pirmenol enantiomer pharmacokinetics can be mostly explained by stereoselective plasma protein binding.

The antiarrhythmic response of coronary artery ligated dogs to pirmenol was similar for both enantiomers and for racemate. Reduction in PVCs as a function of plasma pirmenol concentration was adequately described by a sigmoid $E_{\max }$ model. The $\mathrm{EC}_{50}$ values were similar for $(+)$-pirmenol, (-)pirmenol, and pirmenol racemate, but minimum effective plasma concentration (90\% PVC suppression) was nearly twoto threefold lower for (-)-pirmenol than for (+)-pirmenol or pirmenol racemate. The $\mathrm{EC}_{90}$ differences may be a consequence of different animals being used in each treatment group and the limited number of animals studied. Overall, no statistically significant differences were observed in $\mathrm{EC}_{50}$, $\mathrm{S}$, and $\mathrm{EC}_{90}$ between dogs treated with (+)-pirmenol, (-)pirmenol, or pirmenol racemate.

\section{References and Notes}

1. Mertz, T. E.; Steffe, T. J . J . Cardiovasc. Pharmacol. 1980, 2, 527-541.
2. Steffe, T. J .; Mertz, T. E.; Hastings, S. G.; Potoczak, R. E. Kaplan, H. R. J . Pharmacol. Exp. Ther. 1980, 214(1), 50-57.

3. Hashimoto, K.; Watanabe, K.; Sugiyama, A.J pn. J . Pharmacol. 1988, 48, 273-282.

4. Byrnes, E. W.; McMaster, P. D.; Smith, E. R.; Blair, M. R.; Boyes, R. N., et al. J'. Med. Chem. 1979, 22, 1171-1176.

5. Banitt, E. H.; Schmid, J. R.; Newmark, R. A. J. Med. Chem. 1986, 29, 299-302.

6. Barrett, A. M.; Cullum, V. A. Br. J . Pharmacol. 1968, 34, 4355.

7. Lynch, J . J .; Wilber, D. J .; Montgomery, D. G.; Hsieh, T. M.; Patterson, E.; Lucchesi, B. R. J . Cardiovasc. Pharmacol. 1984 $6,1132-1141$.

8. Turgeon, J.; Uprichard, A. C. G.; Belanger, P. M.; Harron, D. W. G.; Grech-Belanger, O. J . Pharm. Pharmacol. 1991, 43, 630635.

9. Giacomini, K. M.; Giacomini, J . C.; Swezey, S. E.; Harrison, D. C.; Nelson, W. L., et al. J . Cardiovasc. Pharmacol. 1980, 2(6), 825-832.

10. Cook, C. S.; Karim, A.; Sollman, P. Drug. Metab. Dispos. 1982, 10(2), 116-121

11. Walle, T.; Walle, U. K. Res. Commun. Chem. Pathol. Pharmacol. 1979, 23(3), 453-464.

12. Prakash, C.; Koshakji, R. P.; Wood, A. J . J .; Blair, I . A. J . Pharm. Sci. 1989, 78(9), 771-775.

13. Walle, U. K.; Thibodeaux, H.; Privitera, P.J .; Walle, T. Chirality 1989, 1, 192-196.

14. Kidwell, G. A.; Lima, J J .; Schaal, S. F.; Muir, W. W. J . Cardiovasc. Pharmacol. 1989, 13, 644-655.

15. Thompson, J . A.; Wilson, B. K. Pharmacologist 1983, 25(3), 110.

16. Harris, A. S. Circulation 1950, 1, 1318-1328.

17. Moran, N. C.; Moore, J. L.; Holcomb, A. K.; Muschet, G. J . Pharmacol. Exp. Ther. 1962, 136, 327-335.

18. J aniczek, N.; Bockbrader, H. N.; Chang, T.; Amidon, G. L.; Smith, D. E. J. Chromatogr. 1991, 571, 179-187.

19. Gibaldi, M.; Perrier, D. Pharmacokinetics, 2nd ed.; Marcel Dekker: New York, 1982.

20. Wagner, J . G. Fundamentals of clinical pharmacokinetics; Drug Intelligence: Hamilton, IL, 1975.

21. Tozer, T. N.; Gambertoglio, J. G.; Furst, D. E.; Avery, D. S.; Holford, N. H. G. J . Pharm. Sci. 1983, 72, 1442-1446.

22. Nakaya, H.; Hattori, Y.; Endou, M.; Gandou, S.; Kanno, M. Naunyn-Schmi edeberg's Arch. Pharmacol. 1992, 346, 555-562.

\section{Acknowledgments}

This work was supported in part by a gift from Parke-Davis Pharmaceutical Research, Division of Warner-Lambert Company, and by grant R01 GM 35498 from the National Institutes of Health.

J S960369F 